\title{
Serum beta2-microglobulin levels in hepatitis B e antigen-negative chronic hepatitis $B$ patients under long term lamivudine monotherapy: Relationship with virological breakthrough
}

\author{
Ioannis S Elefsiniotis $\mathrm{MD}^{1}$, Nikolaos Scarmeas MD², Irene Glynou MD ${ }^{3}$, Konstantinos D Pantazis MSc ${ }^{1}$, \\ Helen Kada MD ${ }^{3}$, Christos Mavrogiannis MD ${ }^{1}$
}

\begin{abstract}
IS Elefsiniotis, N Scarmeas, I Glynou, KD Pantazis, H Kada, C Mavrogiannis. Serum beta2-microglobulin levels in hepatitis B e antigen-negative chronic hepatitis $\mathrm{B}$ patients under long term lamivudine monotherapy: Relationship with virological breakthrough. Can J Gastroenterol 2004;18(5):307-313.
\end{abstract}

OBJECTIVES: To evaluate the predictive value of serum beta2microglobulin $(\beta 2 \mathrm{~m})$ levels for virological breakthrough in hepatitis B e antigen-negative chronic hepatitis B patients under long term lamivudine monotherapy.

METHODS: Serum $\beta 2 \mathrm{~m}$ levels were calculated at baseline and every three months during lamivudine monotherapy in 25 patients with chronic hepatitis $\mathrm{B}$, using microparticle enzyme immunoassay technology to investigate their association with biochemical, virological and histological outcome data. Cox proportional hazard models were used to investigate the association between serum $\beta 2 \mathrm{~m}$ levels and virological breakthrough.

RESULTS: Seven of 25 (28\%), nine of 25 (36\%) and 14 of 25 (56\%) chronic hepatitis B patients exhibited virological breakthrough at months 12, 24 and 36 of treatment, respectively. All chronic hepatitis B patients who did not show virological breakthrough in the follow-up period exhibited $\beta 2 \mathrm{~m}$ elevation in month 3 of treatment. The duration (in months) of serum $\beta 2 \mathrm{~m}$ elevation was significantly higher in the responders group than the nonresponders group $(7.3 \pm 2.6$ versus $3.8 \pm 3.4, \mathrm{P}=0.02)$. In contrast to patients whose serum $\beta 2 \mathrm{~m}$ levels were increased at three months, patients whose $\beta 2 \mathrm{~m}$ levels were decreased had a 4.6 times higher risk of experiencing virological breakthrough (hazards ratio 4.6, 95\% CI 1.22 to 17.36 ). When age, pretreatment serum alanine aminotransferase and hepatitis B virus DNA levels, and grade of liver disease were simultaneously included in the same Cox model, decreased $\beta 2 \mathrm{~m}$ status was still associated with increased risk of virological breakthrough (hazards ratio 12.2, 95\% CI 1.28 to 116.8 ).

CONCLUSIONS: In hepatitis B e antigen-negative chronic hepatitis $B$ patients under long term lamivudine monotherapy, serum $\beta 2 \mathrm{~m}$ levels at three months of treatment, compared with baseline levels, are good predictors of risk for virological breakthrough.

Key Words: Beta2-microglobulin; Chronic hepatitis B; Lamivudine; Virological breakthrough
Taux sérique de $\beta-2$ microglobuline che $z$ des patients atteints $d$ 'hépatite $B$ chronique, négative à l'égard de l'antigène $\mathrm{HBe}$, et traités à la lamivudine en monothérapie prolongée : lien avec une percée du virus

OBJECTIF : Évaluer la valeur prédictive du taux de $\beta-2$ microglobuline chez des patients atteints d'hépatite $\mathrm{B}$ chronique, négative à l'égard de l'antigène $\mathrm{HBe}$, et traités à la lamivudine en monothérapie prolongée : lien avec une percée du virus.

MÉTHODE : Nous avons mesuré le taux sérique de $\beta-2$ microglobuline au départ, puis aux trois mois, chez 25 patients atteints d'hépatite $B$ et traités à la lamivudine en monothérapie, au moyen du dosage immunoenzymatique de microparticules, afin d'étudier les liens avec les résultats biochimiques, virologiques et histologiques. Le modèle de régression des hasards proportionnels de Cox a servi à examiner le lien entre ce taux sérique et la percée virale.

RÉSULTATS : Sept (28\%), neuf (36\%) et quatorze patients (56\%) sur les 25 à l'étude ont présenté une augmentation de la charge virale au bout de 12, 24 et 36 mois respectivement. Tous les patients atteints d'hépatite B chronique chez qui le virus n'a pas fait de percée au cours du suivi ont vu le taux de $\beta-2$ microglobuline augmenter après trois mois de traitement. La période (mois) durant laquelle le taux sérique de $\beta-2$ microglobuline est resté élevé était sensiblement plus longue chez les sujets répondants que chez les sujets non répondants $(7,32,6$ contre $3,83,4 ; \mathrm{P}=0,02)$. Contrairement aux patients chez qui le taux sérique de $\beta-2$ microglobuline avait augmenté, ceux chez qui ce taux avait diminué avaient 4,6 fois plus de risques de connaître une percée virale (rapport des taux d'incidence : 4,6; IC à $95 \%$ : 1,22 à 17,36). Même lorsque l'âge, le taux sérique d'alanine-aminotransférase avant le traitement, le taux d'ADN du virus de l'hépatite $\mathrm{B}$ et le degré d'atteinte hépatique étaient intégrés dans le même modèle de Cox, la diminution du taux de $\beta-2$ microglobuline était toujours associée à une augmentation du risque de percée du virus (rapport des taux d'incidence : 12,2; IC à $95 \%$ : 1,28 à 116,8).

CONCLUSION : Le taux sérique de $\beta$ - 2 microglobuline après trois mois de traitement, comparativement au départ, constitue un bon prédicteur de risque de percée virale chez les patients atteints d'hépatite $B$ chronique, négative à l'égard de l'antigène HBe, et traités à la lamivudine en monothérapie prolongée.

${ }^{1}$ Department of Hepatogastroenterology, University of Athens, 'Helena Venizelou' Hospital, Athens, Greece; ${ }^{2}$ New York Presbyterian Hospital, Columbia University, New York, USA; ${ }^{3}$ Department of Microbiology, 'Helena Venizelou' Hospital, Athens, Greece

Correspondence: Dr Ioannis S Elefsiniotis, Carchidonos 9, A Glyfada GR-16562 Greece. Telephone 003-0-210-963-0312,

fax 003-0-210-778-7807,e-mail ielefs@acn.gr

Received for publication October 9, 2003. Accepted March 19, 2004 
Chronic hepatitis B (CHB) is a common disease with an Cestimated global prevalence of 350 million chronically infected patients, according to the World Health Organization (1). Hepatitis B e antigen ( $\mathrm{HbeAg}$ )-negative $\mathrm{CHB}$ accounts for $7 \%$ to $30 \%$ of patients with $\mathrm{CHB}$ worldwide, with the highest rates reported in Mediterranean Europe and Asia (2). It results from infection with hepatitis $B$ virus (HBV) mutants that are unable to produce $\mathrm{HbeAg}$ (3). In Greece, it is estimated that more than $95 \%$ of patients with HbeAg-negative $\mathrm{CHB}$ are infected with the precore mutant HBV variant (4). These patients often appear to have more severe liver disease than that observed in patients infected with the wild type form of the virus, and treatment with interferon (IFN)-alpha is associated with suboptimal responses, high relapse rates and poor compliance $(5,6)$.

Lamivudine is an oral nucleoside analogue that has potent antiviral properties against HBV and human immunodeficiency virus (HIV). Studies in HbeAg-positive (7) and HbeAgnegative (8) $\mathrm{CHB}$ patients demonstrate that lamivudine treatment results in rapid and consistent suppression of serum HBV DNA levels with normalization of aminotransferases and significant improvement of liver histology in the majority of patients. Extended lamivudine treatment increases the emergence of HBV variants, which have changes in the tyrosinemethionine-aspartate-aspartate amino acid (YMDD) locus of the HBV DNA polymerase sequence and exhibit reduced susceptibility to the drug (9-12). However, the clinical impact of these mutations is controversial $(9-11)$ and the prediction of virological breakthrough (VB) is an issue needing further investigation.

Beta2-microglobulin $(\beta 2 \mathrm{~m})$ plays a key role in influencing the immune response to viral infections because it is an integrating part of the major histocompatibility complex or human leukocyte antigen (HLA) (13). In comparison with controls, patients with chronic viral hepatitis manifest an enhanced hepatocellular display of class I HLA antigens together with rising serum $\beta 2 \mathrm{~m}$ levels $(13,14)$. Both hepatic class I HLA antigens and serum $\beta 2 \mathrm{~m}$ levels correlated positively with duration and severity of liver disease $(13,14)$. Moreover, IFN treatment significantly increased serum $\beta 2 \mathrm{~m}$ levels, offering a Th1dominant environment to patients with chronic viral hepatitis, irrespective of therapy outcome (14-16). However, in at least two studies, hepatocyte $\beta 2 \mathrm{~m}$ expression significantly decreased after IFN treatment $(17,18)$ following the reduction of histological activity of liver disease. The alterations of serum $\beta 2 \mathrm{~m}$ levels in CHB patients under long term lamivudine treatment have not been investigated yet.

In the present study, we sought to record the alterations of serum $\beta 2 \mathrm{~m}$ levels in HbeAg-negative CHB patients under long term lamivudine monotherapy, and to investigate their association with biochemical, virological and histological outcome data. We hypothesized that serum $\beta 2 \mathrm{~m}$ levels may be a predictor of VB or biochemical breakthrough (BB).

\section{METHODS}

Between March 1998 and August 1999, a total of 25 consecutive hepatitis B surface antigen ( $\mathrm{Hbs} \mathrm{Ag}$ )-positive patients (23 males) were enrolled prospectively in the study (GRLM01, GlaxoSmithKline, Greece). All patients were treated with oral lamivudine (100 mg daily) for 36 months. Patients were evaluated clinically, biochemically and serologically at entry and every three months during treatment. To allow for reasonable time for breakthrough to occur, only patients with at least 18 months of follow-up were included in the current analyses.

To be eligible, patients had to fulfill the following criteria: age greater than 18 years; detectable $\mathrm{HbsAg}$ in serum for at least six months; HbeAg negativity; antibody to HbeAg positivity with signs of active viral replication (serum HBV DNA-positive); serum alanine aminotransferase (ALT) levels above the normal range on at least two separate occasions in the previous six months; and absence of previous immunomodulatory and/or antiviral treatment for hepatitis. HBV sequencing to confirm genotypic precore mutations was not performed. Patients were excluded if they were infected with hepatitis $C$ and/or hepatitis D virus, were infected with HIV, had decompensated liver disease (Child-Pugh B or C), had evidence of autoimmune hepatitis (antinuclear antibody titre of at least 1:160) or had a positive clinical history for other chronic liver disease. Moreover, patients were excluded from the study if they had a positive clinical history for other chronic diseases or if they were under any other medication. Pregnant and breastfeeding women were also excluded.

Liver biopsy was done for all patients at baseline and at month 12 of the study. A single pathologist evaluated all biopsy specimens that were scored according to the Ishak scoring system (grade 0 to 18 , stage 0 to 6 ) (19). Histological response was defined as at least a two-point reduction in the necroinflammatory score (grade) between the pretreatment and the month 12 biopsies, and at least the same fibrosis score (stage).

Routine biochemical and hematological tests were performed using automated techniques. Virological evaluation (HBV DNA) was done at baseline and at months six, 12, 24 and 36 of treatment. $\mathrm{HbsAg}, \mathrm{HbeAg}$, antibody to $\mathrm{HbeAg}$ and antibody to $\mathrm{HbsAg}$ were measured using routine commercially available enzyme immunoassays (Abbott Laboratories, USA). HBV DNA was quantified with the use of a commercially available polymerase chain reaction assay (Amplicor, Roche, Switzerland) with a lower limit of quantification of 400 copies $/ \mathrm{mL}$. Detection of HBV polymerase YMDD variants was performed as described by Lai et al (7), using a restriction fragment-linked polymorphism assay.

BB was defined as an ALT flare (ALT greater than 40 IU/L) during lamivudine treatment, after at least one previous test had been under normal range (ALT 40 IU/L or less).

VB was defined as an HBV DNA reappearance (HBV DNA greater than 400 copies $/ \mathrm{mL}$ ) during lamivudine treatment, after at least one previous test had been under normal range (HBV DNA 400 copies/mL or less).

\section{$\beta 2 \mathrm{~m}$}

Serum was collected from patients at baseline and every three months during lamivudine treatment and was stored at $-85^{\circ} \mathrm{C}$. Serum $\beta 2 \mathrm{~m}$ levels were calculated using microparticle enzyme immunoassay technology (20), which used submicron microparticles coated with a capture molecule specific for the analyte being measured (Abbott Laboratories, USA). Serum sample and microparticles (captured molecules) were transferred to the incubation well of the reaction cell. During the incubation period, analytes bound to the microparticles, creating an immune complex. The reaction mixture was aspirated from the incubation well to another cell where it was washed to remove unbound materials. Alkaline phosphate-labelled conjugate was then transferred in the cell, where it bound to the immune complex to complete the antibody-analyte-conjugate 'sandwich'. The new complex was washed again and a dispenser added the substrate 4-methylumbelliferyl 
phosphate. The alkaline phosphate conjugate catalyzed the hydrolysis of 4-methylumbelliferyl phosphate to 4-methylumbelliferone. The rate at which 4-methylumbelliferone was generated in the cell was proportional to the concentration of analyte in the serum sample.

Written informed consent was obtained from each patient for his or her participation in the study. The Hippokration Institutional Review Board reviewed and approved this project. The study protocol conforms to the ethical guidelines of the Declaration of Helsinki.

\section{Statistical analysis}

$\beta 2 \mathrm{~m}$ levels were treated as a continuous variable in initial analyses. Two variables relating to $\beta 2 \mathrm{~m}$ were subsequently calculated. First, a continuous variable was created, reflecting the number of three-month intervals for which $\beta 2 \mathrm{~m}$ was rising, in relation to baseline levels. Second, a dichotomous variable reflecting the status of either $\beta 2 \mathrm{~m}$ elevation or decline at three-month intervals was created: this variable took the value of zero if $\beta 2 \mathrm{~m}$ increased at three months (compared with baseline) and the value of one if $\beta 2 \mathrm{~m}$ either remained the same or decreased at three months (compared with baseline).

Age, serum ALT levels and histological activity index (HAI, grade) of liver disease were all treated as continuous variables in the analyses. Initial HBV DNA levels were dichotomized into two groups: high viral load (greater than $10^{6}$ copies $/ \mathrm{mL}$ ); and low viral load ( $10^{6}$ copies $/ \mathrm{mL}$ or less).

Student's $t$ test and $\chi^{2}$ analyses were used to examine the association between the presence of VB and other potentially interactive variables including age, ALT levels, BB, HAI, serum HBV DNA levels and serum $\beta 2 \mathrm{~m}$ levels. $A \mathrm{P}<0.05$ was considered significant.

Survival analyses (Cox proportional hazard [21]) were used to investigate the association between serum $\beta 2 \mathrm{~m}$ levels (predictor) and VB (outcome). Participants were considered to have failed at the time of the first follow-up visit at which VB was documented. For participants who did not manifest VB, the last follow-up evaluation was used for censoring. Therefore, the Cox model's time axis was the duration of follow-up until either VB or the last evaluation without VB. The initial Cox proportional hazard models used either the duration of $\beta 2 \mathrm{~m}$ elevation (continuous variable) or the elevation versus decline status at three-month intervals of $\beta 2 \mathrm{~m}$ (dichotomous variable) as a predictor. In subsequent Cox models, potential confounders (age, ALT, HBV DNA, HAI) were simultaneously included along with $\beta 2 \mathrm{~m}$ status at three months of follow-up in the same Cox model.

In addition, the changes of $\beta 2 \mathrm{~m}$ levels over time were explored, as well as their association with VB using generalized estimating equations (GEE) (22). GEE take into account the multiple assessments per subject and the fact that the characteristics of the same individual over time $(\beta 2 \mathrm{~m}$ scores for this analysis) are likely to be correlated. The repeated measures for each subject are treated as a cluster. $\beta 2 \mathrm{~m}$ was the dependent variable in this model. The model initially considered the effect of time (in months) for $\beta 2 \mathrm{~m}$ measurements. In line with the primary hypothesis (that changes of $\beta 2 \mathrm{~m}$ in the beginning of the lamivudine treatment period would predict VB), only the first six-month $\beta 2 \mathrm{~m}$ measurements were included. The model also considered the effects of the group (VB versus no VB) and their interaction. A significant time effect indicated a marked change in $\beta 2 \mathrm{~m}$ measurements over time (across both groups combined). A significant group effect indicated a significant difference in $\beta 2 \mathrm{~m}$ values at baseline. A significant

\begin{tabular}{|c|c|c|c|c|}
\hline & $\begin{array}{c}\text { All CHB } \\
\text { patients } \\
(n=25)\end{array}$ & $\begin{array}{c}\text { Responders } \\
(n=11)\end{array}$ & $\begin{array}{l}\text { YMDD } \\
(n=14)\end{array}$ & $\mathbf{P}$ \\
\hline Age (years) & $42.8 \pm 13.6$ & $43.9 \pm 5$ & $41.9 \pm 12.9$ & 0.75 (NS) \\
\hline ALT (IU/L) & $218 \pm 106.1$ & $263.9 \pm 115.8$ & $183.6 \pm 87.7$ & 0.09 (NS \\
\hline $\begin{array}{c}\text { HBV DNA } \times 10^{6} \\
(\text { copies } / \mathrm{mL} \text { ) }\end{array}$ & $6.83 \pm 14.22$ & $1.27 \pm 2.57$ & $11.00 \pm 17.85$ & 0.09 (NS) \\
\hline Grade (0 to 18$)$ & $7.0 \pm 3.3$ & $6.8 \pm 3.5$ & $7.1 \pm 3.3$ & 0.84 (NS \\
\hline Stage (0 to 6$)$ & $3.2 \pm 1.5$ & $3.1 \pm 1.3$ & $3.4 \pm 1.9$ & 0.65 (NS) \\
\hline $\begin{array}{l}\beta 2 \mathrm{~m}(\mathrm{mg} / \mathrm{dL}) \\
\quad \text { (baseline levels) }\end{array}$ & $1695.5 \pm 348.1$ & $1588.8 \pm 391.6$ & $1775.5 \pm 304.1$ & 0.23 (NS) \\
\hline $\begin{array}{l}\text { Duration of } \beta 2 \mathrm{~m} \\
\text { elevation } \\
\text { (months) }\end{array}$ & $5.3 \pm 3.5$ & $7.3 \pm 2.6$ & $3.8 \pm 3.4$ & $0.02(\mathrm{~S})$ \\
\hline $\begin{array}{l}\beta 2 \mathrm{~m} \text { elevation } \\
\text { in } 3 \text { months (\%) }\end{array}$ & $19 / 25(76 \%)$ & $11 / 11(100 \%)$ & $8 / 14(57.1 \%)$ & $0.03(\mathrm{~S})$ \\
\hline
\end{tabular}

With the exception of the last row, mean values $\pm S D$ are presented. ALT Alanine aminotransferase; $\beta 2 m$ beta2-microglobulin; HBV Hepatitis $B$ virus; NS Not significant, $P>0.05$; S Significant, $P<0.05$; YMDD Tyrosinemethionine-aspartate-aspartate amino acid locus of the HBV DNA polymerase sequence

time $\times$ group effect indicated significantly different rates of change of $\beta 2 \mathrm{~m}$ over time for one group versus the other.

\section{RESULTS}

All CHB patients tolerated lamivudine therapy well and completed the treatment period. None of the patients was lost from the follow-up. Mean overall follow-up (since start of lamivudine treatment) for the whole group was $31.4 \pm 6.0$ months (range 24 to 36 months). Mean follow-up for the patients who exhibited VB $(31 \pm 6.2$ months $)$ did not differ from follow-up for patients without VB $(32 \pm 6.0$ months) $(\mathrm{P}=0.71)$. None of the treated $\mathrm{CHB}$ patients lost $\mathrm{HbsAg}$ and none showed $\mathrm{HbsAg}$ seroconversion during the lamivudine treatment period. Mild elevation of serum amylase levels, with no clinical significance, was observed in three of 25 (12\%) treated patients. One patient developed a macular skin rash during the first two weeks of treatment, which disappeared without intervention in the following two weeks while he was on lamivudine treatment.

The demographic, laboratory and histological features of $\mathrm{CHB}$ patients at entry are shown in Table 1 . There was no association between histological findings (grade, stage) and either serum ALT levels ( $\mathrm{P}=0.719$ and $\mathrm{P}=0.486$, respectively) or serum HBV DNA levels $(\mathrm{P}=0.784$ and $\mathrm{P}=0.542$, respectively). Patients with a higher level of fibrosis (stage) at entry were older $(\mathrm{P}=0.021)$. Three of $25 \mathrm{CHB}$ patients $(12 \%)$ had evidence of cirrhosis with ongoing inflammatory activity at baseline liver biopsy (Child-Pugh A).

Both serum ALT levels and serum HBV DNA titres showed a sharp decline during the first six months of therapy. Serum ALT levels were under the upper normal limits (less than $40 \mathrm{IU} / \mathrm{L}$ ) and serum HBV DNA were negative (less than 400 copies $/ \mathrm{mL}$ ) in all CHB patients who participated in the study, at month 6 of lamivudine treatment. In the first year of treatment, seven of 25 (28\%) CHB patients exhibited VB and 


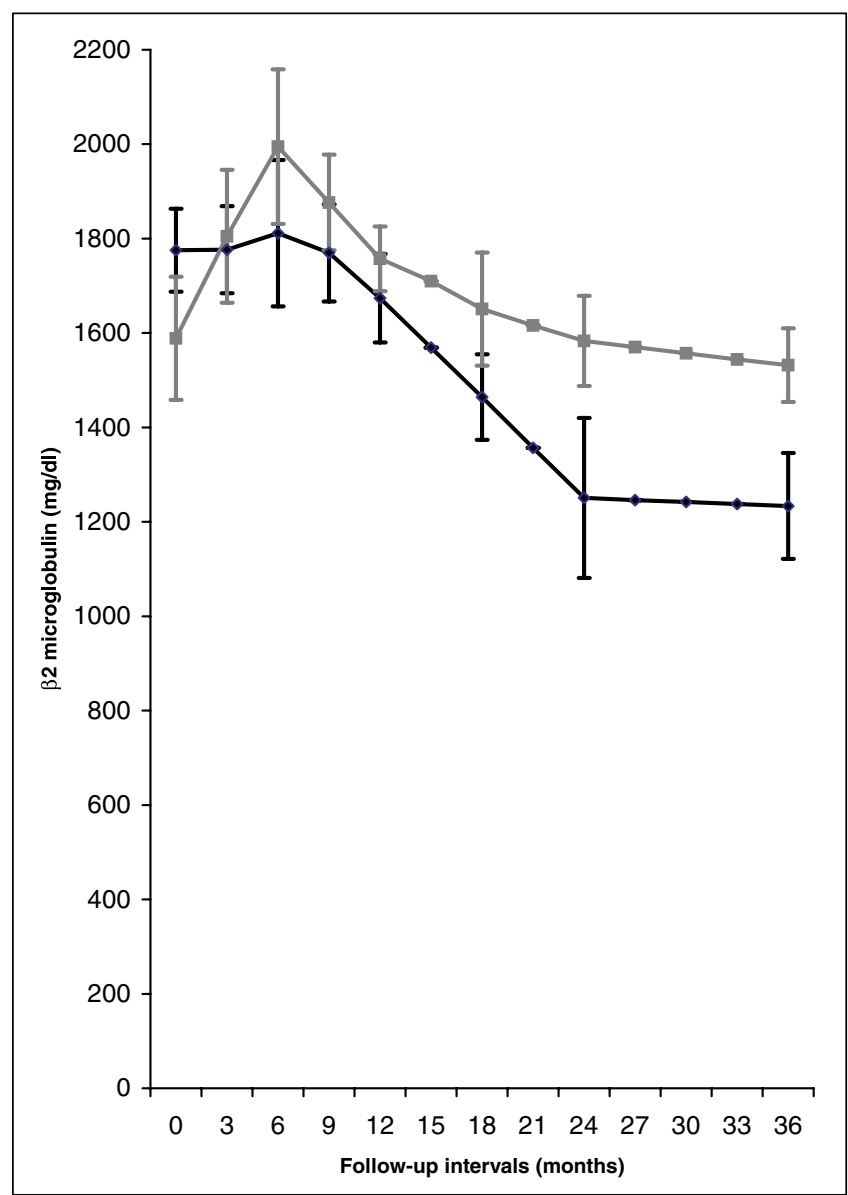

Figure 1) Mean serum beta 2 ( $\beta 2)$-microglobulin $(\beta 2 m)$ levels for each follow-up interval, plotted separately for the group of patients who exhibited virological breakthrough (rhombuses-black line) and for the group of patients who did not (squares-grey line). As evidenced from the chart, mean serum $\beta 2 \mathrm{~m}$ levels remained stable (did not increase) for approximately nine months in patients who exhibited virological breakthrough, and steeply increased for approximately six month in patients who did not. Subsequently, serum $\beta 2 \mathrm{~m}$ levels declined in both groups

four of the seven patients (16\% of the total CHB patients) showed both $\mathrm{VB}$ and $\mathrm{BB}$. At month 12, the proportion of lamivudine-treated patients who were complete responders (neither VB nor BB) was as high as $72 \%$. Both serum ALT levels and serum HBV DNA levels were significantly reduced after the 12 -month treatment period. Moreover, there was a significant reduction in the histological score both for grade and stage of liver disease. In particular, 21 of $25 \mathrm{CHB}$ patients $(84 \%)$ showed at least a two-point reduction in the histological score for grade, three of 25 (12\%) showed no improvement of liver histology and only one (4\%) showed worsening of the necroinflammatory activity of liver disease. All four patients with no improvement or worsening of liver histology appeared with both $\mathrm{VB}$ and $\mathrm{BB}$, whereas the other three patients who appeared with VB but no BB showed a significant improvement of liver histology.

Nine of $25(36 \%)$ and 14 of $25(56 \%)$ CHB patients exhibited VB at months 24 and 36 of lamivudine monotherapy, respectively.
TABLE 2

Cox proportional hazard model predicting virological breakthrough by serum beta2-microglobulin $(\beta 2 \mathrm{~m})$ levels

\begin{tabular}{lccc}
\hline & Variable & HR & $\mathbf{9 5 \% ~ C l}$ \\
\hline$\beta 2 \mathrm{~m}$ & Continuous & 1.25 & 1.03 to $1.52^{*}$ \\
$\begin{array}{c}\text { Decline versus } \\
\text { elevation }\end{array}$ & 4.6 & 1.22 to $17.36^{*}$ \\
& & &
\end{tabular}

Results are presented with $\beta 2 m$ used as a continuous variable (number of months of $\beta 2 m$ elevation) or as a dichotomous variable (decline versus elevation of serum $\beta 2 \mathrm{~m}$ levels at three months, compared with baseline levels). The hazard ratio (HR) for $\beta 2 m$ as a continuous variable reflects risk for virological breakthrough for each month less of $\beta 2 m$ elevation. *Indicates that the HR does not include 1

Demographics, and biochemical, virological and histological information variables of patients who did and did not exhibit VB, as well as for the whole group of patients, are presented in Table 1 . The two groups were comparable for all the baseline parameters (age, ALT, HBV DNA, grade, stage, $\beta 2 \mathrm{~m}$ ) but they differed significantly in the pattern of $\beta 2 \mathrm{~m}$ curve during treatment. In particular, all patients who did not show VB in the follow-up period exhibited $\beta 2 \mathrm{~m}$ elevation in month three of treatment, whereas only $57.1 \%$ of those who exhibited $\mathrm{VB}$ showed $\beta 2 \mathrm{~m}$ elevation $(\mathrm{P}=0.03)$. Moreover, the duration (in months) of serum $\beta 2 \mathrm{~m}$ elevation was significantly higher in the responders than the nonresponders $(7.3 \pm 2.6$ versus $3.8 \pm 3.4, \mathrm{P}=0.02)$. The different patterns of $\beta 2 \mathrm{~m}$ in relation to recurrence are presented in Figure 1. It is evident that mean serum $\beta 2 \mathrm{~m}$ levels remained stable for about nine months in patients who exhibited VB, while there were steep increases for about six months in the responders group. Subsequently, $\beta 2 \mathrm{~m}$ values declined in both groups.

Mean baseline $\beta 2 \mathrm{~m}$ levels were slightly higher in patients with high initial HBV DNA compared with patients with low initial HBV DNA (1878 mg/dL versus $1622 \mathrm{mg} / \mathrm{dL}, \mathrm{t}=-1.58$, $\mathrm{P}=0.13$ ). Patients with higher baseline serum $\beta 2 \mathrm{~m}$ levels had slightly higher baseline HAI $(\mathrm{r}=0.39, \mathrm{P}=0.08)$ and slightly higher baseline ALT levels $(r=0.25, P=0.28)$. Patients with high initial HBV DNA levels had a shorter duration of $\beta 2 \mathrm{~m}$ elevation (6.2 months for the low versus three months for the high initial HBV DNA group, $\mathrm{t}=1.49, \mathrm{P}=0.186$ ). Moreover, 99.3\% of the initial low HBV DNA group of patients exhibited $\beta 2 \mathrm{~m}$ elevation at three months, while only $33 \%$ of the initial high HBV DNA group did the same $\left(\chi^{2}=8.5, \mathrm{P}=0.004\right)$.

\section{Cox models}

Survival analyses have the advantage of combining information about frequency of events and time of their occurrence. The reported hazard ratios (HR) indicate risk of having VB for each time unit of follow-up. Therefore, they reflect not only how likely it is for a patient to recur but also how quickly he or she may be expected to do so.

When the duration of $\beta 2 \mathrm{~m}$ elevation was used as a predictor, a lower score (decreased duration of $\beta 2 \mathrm{~m}$ elevation) was associated with an increased risk of $\mathrm{VB}(\mathrm{HR}=1.25,95 \% \mathrm{CI}$ 1.03 to 1.52 ) (Table 2). It is of importance to note that, in this model, the HR reflects the increase in risk for VB for each additional unit of the predictor (eg, each month less for which serum $\beta 2 \mathrm{~m}$ failed to elevate). According to this result, in comparison with a patient whose serum $\beta 2 \mathrm{~m}$ levels continued to increase for 12 months, a patient whose $\beta 2 \mathrm{~m}$ continued to increase for only nine months had 1.95 times higher risk of 


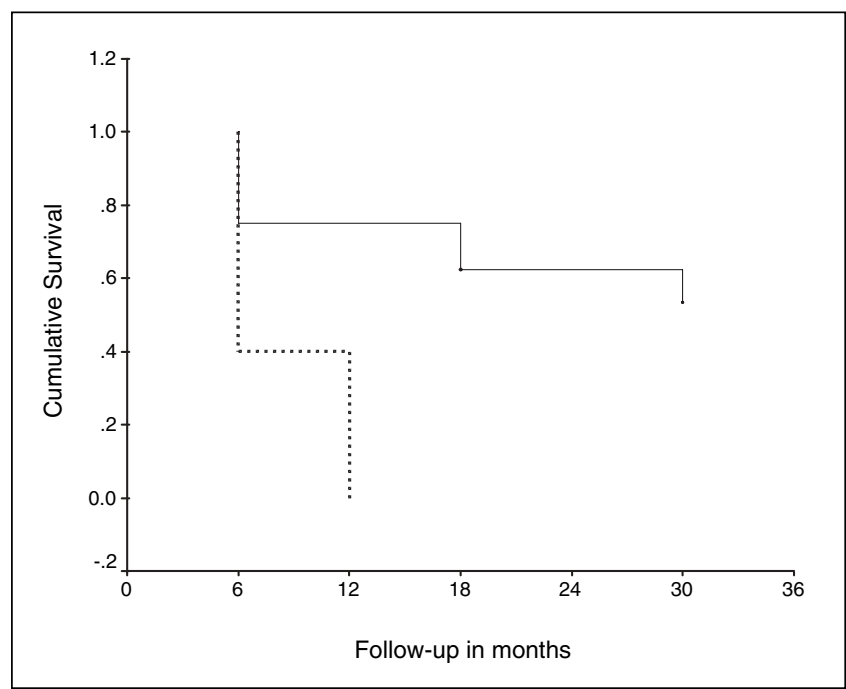

Figure 2) Kaplan-Meier survival curves comparing cumulative survival (percentage of patients remaining free of virological breakthrough) in chronic hepatitis B patients with elevated serum beta2-microglobulin $(\beta 2 \mathrm{~m})$ levels at three months (solid line) versus decreased $\beta 2 \mathrm{~m}$ levels at three months (dashed line). All patients with decreased serum $\beta 2 \mathrm{~m}$ levels at three months experienced virological breakthrough in month 12 of lamivudine treatment

developing $\mathrm{VB}$, a patient whose $\beta 2 \mathrm{~m}$ continued to increase for only six months had a 3.8 times higher chance of developing $\mathrm{VB}$, and a patient whose $\beta 2 \mathrm{~m}$ continued to increase for only three months had a 7.4 times higher risk for developing VB.

When serum $\beta 2 \mathrm{~m}$ levels were used in their dichotomous form (reflecting elevated versus declined status at three-month intervals), there was again an inverse association between $\beta 2 \mathrm{~m}$ levels and VB ( $\mathrm{HR}=4.6,95 \%$ CI 1.22 to 17.36 ) (Table 2). In other words, in comparison with patients whose serum $\beta 2 \mathrm{~m}$ levels were increased at three months, subjects whose $\beta 2 \mathrm{~m} \mathrm{lev}$ els were decreased at three months had a 4.6 times higher risk of experiencing VB. Cumulative survival curves for VB for patients with three-month $\beta 2 \mathrm{~m}$ elevation or decline are presented in Figure 2.

When age, baseline ALT levels, initial serum HBV DNA levels and grade of liver disease (HAI) were simultaneously included in the same Cox model (along with $\beta 2 \mathrm{~m}$ status at three months of follow-up), decreased $\beta 2 \mathrm{~m}$ status was still associated with an increased risk of VB ( $\mathrm{HR}=12.23,95 \%$ CI 1.28 to 116.80 ) (Table 3).

\section{GEE models}

There was a significant time effect $(\beta=67.7, \mathrm{P}<0.0001)$, indicating an overall significant increase of $\beta 2 \mathrm{~m}$ over time (for the first six months). The group effect was nonsignificant ( $\beta=182.5, P=0.21)$, indicating similar $\beta 2 \mathrm{~m}$ values at baseline across the two groups. The interaction (time $\times$ group) effect $(\beta=-61.7)$ indicated a higher slope of increase of $\beta 2 \mathrm{~m}$ over the first six months for patients who did not exhibit VB (compared with those who exhibited VB); the effect was borderline nonsignificant $(P=0.08)$. In a subsequent GEE model, the following predictors were simultaneously included: time, group, time $\times$ group, age, baseline $\beta 2 \mathrm{~m}$ values, baseline HBV DNA, baseline ALT levels and grade (HAI). The results were unchanged.

\begin{tabular}{|c|c|c|c|}
\hline & Variable & HR & $95 \% \mathrm{Cl}$ \\
\hline Age (years) & Continuous & 0.98 & $0.92-1.05$ \\
\hline ALT (IU/L) & Continuous & 0.99 & $0.98-1.00$ \\
\hline Grade (0 to 18$)$ & Continuous & 1.26 & $0.98-1.63$ \\
\hline HBV DNA (copies $/ \mathrm{mL}$ ) & High versus low & 1.94 & $0.26-14.26$ \\
\hline$\beta 2 \mathrm{~m}(\mathrm{mg} / \mathrm{dL})$ & $\begin{array}{l}\text { Decline versus } \\
\text { elevation }\end{array}$ & 12.23 & $1.28-116.80^{*}$ \\
\hline
\end{tabular}

The model simultaneously includes age, baseline values for alanine aminotransferase (ALT), grade of liver disease and initial serum hepatitis B virus (HBV)-DNA as covariates. *Indicates that the hazard ratio (HR) does not include 1

Therefore, the associations between changes in $\beta 2 \mathrm{~m}$ levels and VB were similar to the Cox analyses. The borderline nonsignificant effect of the interaction term in the GEE analyses may be due to lower power compared with survival analyses, which take into account not only failure status (VB versus no $\mathrm{VB}$ ), but also time to failure (duration until either VB or last evaluation without $\mathrm{VB})$.

\section{DISCUSSION}

Lamivudine is an oral nucleoside analogue with potent antiviral activity against HBV and exhibits high response rates, usually at the end of the first year of treatment $(7,8)$. However, response rates tend to decrease with the prolongation of lamivudine monotherapy (23) and breakthroughs due to YMDD mutant accumulation, culminating in the development of BBs in most HbeAg-negative $\mathrm{CHB}$ patients (11). Early prognosis of $\mathrm{VB}$ during lamivudine treatment is very useful in order to predict the clinical outcome and to modify the medication. Initial serum HBV DNA levels seem to be a good predictor of virological response (7-9). Similarly, quantitative HBV DNA testing during lamivudine treatment provides prognostic information: there is a low likelihood of response in patients who remain positive at month three of treatment (24). However, HBV DNA testing is expensive and requires highly qualified laboratories. In contrast, the calculation of serum $\beta 2 \mathrm{~m}$ levels using microparticle enzyme immunoassay technology is obviously a cheaper and easier method to use.

Chronic HBV infection is characterized by T cell hyporesponsiveness, and stimulation of HBV-specific $\mathrm{T}$ cell responses in patients with $\mathrm{CHB}$ is believed to represent a rational strategy to treat persistent infection (25). Activation of T cell immune responses leads to elimination of intracellular virus by cytolytic destruction of infected hepatocytes and suppression of viral gene expression, which is caused by cytokines such as IFNgamma and tumour necrosis factor-alpha, which are secreted by activated $T$ cells (Th1 subset) at the site of infection (26-28). This is involved in the T-cell response, providing help to cytotoxic $\mathrm{T}$ lymphocytes, and mediating HBV elimination by cytolytic and noncytolytic mechanisms (29). Serum $\beta 2 \mathrm{~m}$ levels are significantly elevated in patients with chronic viral hepatitis compared with healthy controls $(13,15)$ and increase significantly on IFN-alpha treatment (14-16), representing a Th1-dominant immune response. To our knowledge, serum $\beta 2 \mathrm{~m}$ levels in $\mathrm{CHB}$ patients under long term lamivudine 
monotherapy, which represents a classical antiviral treatment, has not been investigated.

In our study, we found a significant correlation between the decline of serum $\beta 2 \mathrm{~m}$ levels (especially during the first three months of treatment) and the risk for VB in HbeAg-negative $\mathrm{CHB}$ patients under long term lamivudine monotherapy. Moreover, we found that the longer duration of $\beta 2 \mathrm{~m}$ elevation is associated with a reduced risk of VB. In particular, we found that for each additional month where serum $\beta 2 \mathrm{~m}$ continued to elevate, the risk for VB reduced by approximately $80 \%$ (or for each month less of $\beta 2 \mathrm{~m}$ elevation, the risk increased by 1.25 times). The serum $\beta 2 \mathrm{~m}$ elevation in the responders group possibly represents an elevated endogenous immune response in this group of patients. The majority $(99.3 \%)$ had low initial serum HBV DNA levels, a finding that supports this hypothesis. These patients show an 'IFN-like' $\beta 2 \mathrm{~m}$ curve following the first months of lamivudine treatment.

Serum $\beta 2 \mathrm{~m}$ levels have been anticipated to represent the turnover of HLA antigens and are associated with lymphocyte proliferation and activation (30). Boni et al (31) suggest that lamivudine treatment can overcome cytotoxic $\mathrm{T}$ cell hyporesponsivenes in treated $\mathrm{CHB}$ patients by reducing the levels of viremia. High viral load reduces the number and the potential activity of circulating HBV-specific T lymphocytes compared with low viral load in CHB patients (32), suggesting the dominant role of the control of viral replication. High viral load and intrahepatic viral replication result in decreased hepatocellular presentation of class I HLA molecules and act as a negative modulator of natural killer cell activity (33). Lamivudine treatment reduced the intrahepatic viral load (34), possibly resulting in the modulation of $\mathrm{T}$ cellular immune response. On the other hand, Marinos et al (35) suggest that the profound inhibition of HBV replication by nucleoside analogues does not restore the impaired virus-specific T cell responses.

The association between the initial low HBV DNA levels and serum $\beta 2 \mathrm{~m}$ elevation observed in our study implies an activation of host $\mathrm{T}$ cellular immune responses before the beginning of lamivudine treatment in the responders group, which leads to the control of viremia in the long term. The comparable baseline ALT levels and histological findings between the

\section{REFERENCES}

1. World Health Organization. The World Health Report. Geneva: World Health Organization, 1998.

2. Schalm SW, Thomas HB, Hadziyannis SJ. Chronic hepatitis B. Prog Liver Dis 1990;9:443-62.

3. Carman WF, Jacyna MR, Hadziyannis S, et al. Mutation preventing formation of e antigen in patients with chronic Hepatitis B infection. Lancet 1989;2:588-91.

4. Laras A, Koskinas J, Avgidis K, Hadziyannis SJ. Incidence and clinical significance of hepatitis $B$ virus precore gene translation initiation mutations in e antigen-negative patients. J Viral Hepat 1998;5:241-8

5. Brunetto MR, Giarin M, Saracco G, et al. Hepatitis B virus unable to secrete e antigen and response to interferon in chronic hepatitis B. Gastroenterology 1993;105:845-50.

6. Hadziyannis S, Bramou T, Makris A, Moussoulis G, Zignego L, Papaionannou C. Interferon alpha-2b treatment of $\mathrm{HbeAg}$ negative/serum HBV DNA positive chronic active hepatitis type B. J Hepatol 1990;11(Suppl 1):S133-6.

7. Lai CL, Chien RN, Leung NW, et al. A one year trial of lamivudine for chronic hepatitis B. N Engl J Med 1998;339:61-8.

8. Tassopoulos NC, Volpes R, Pastore G, et al. Efficacy of lamivudine in patients with hepatitis B e antigen-negative/Hepatitis B DNA positive (precore mutant) chronic hepatitis B. Hepatology 1999;29:889-96. two groups and the ALT normalization during the first months of treatment in both groups suggest an additive $T$ cellularmediated, noncytolytic inhibition of virus replication in the responders group, as has been shown by other studies (36), a possibility that needs further investigation. In a recent study, Santantonio et al (37) found that combination treatment (lamivudine plus IFN) in HbeAg-negative CHB patients was as beneficial as lamivudine monotherapy, but the combination regimen appeared to delay or prevent the emergence of YMDD variants. The significant elevation of serum $\beta 2 \mathrm{~m}$ levels following IFN treatment and the results of our study suggest that close monitoring of serum $\beta 2 \mathrm{~m}$ levels in HbeAg-negative $\mathrm{CHB}$ patients under lamivudine monotherapy could result in early recognition of the group of relapsers and the possible addition of immunomodulatory and/or other antiviral drugs.

Initial serum HBV DNA levels differed between the two groups (responders versus nonresponders) as expected from the literature (7-9), but not significantly (Table 1). Also, initial serum HBV DNA status was not a significant predictor in the adjusted Cox model (Table 3). This may be because of decreased power of the current study due to the small number of patients. However, serum $\beta 2 \mathrm{~m}$ status remained significant in the prognosis of $\mathrm{VB}$, in the adjusted Cox model (which was adjusted for baseline HBV DNA status). These results suggest that there is a predictive value of serum $\beta 2 \mathrm{~m}$ levels compared with baseline ones for the emergence of HBV DNA polymerase mutants in $\mathrm{CHB}$ patients under lamivudine treatment.

In conclusion, serum $\beta 2 \mathrm{~m}$ levels during the first months of treatment are a good predictor of VB in HbeAg-negative CHB patients under long term lamivudine monotherapy. Decreased serum $\beta 2 \mathrm{~m}$ levels at month three of lamivudine treatment are associated with 4.6-times higher risk of virological relapse in comparison with patients whose serum $\beta 2 \mathrm{~m}$ levels increased at the same time. The shorter duration of serum $\beta 2 \mathrm{~m}$ elevation in these patients is associated with an increased risk of VB in the long term, suggesting frequent follow-up visits and possibly reinforcement of treatment strategies.

ACKNOWLEDGEMENTS: The study was partially supported by Glaxo-Smith Kline (GRLM01 protocol).

9. Leung NWY, Lai CL, Chang TT, et al. Extended lamivudine treatment in patients with chronic hepatitis B enhances hepatitis B e antigen seroconversion rates: Results after 3 years of therapy. Hepatology 2001;33:1527-32.

10. Rizzetto M, Santantonio T, Buti M, et al. Benefits of extended lamivudine treatment in patients with $\mathrm{HbeAg}$ - negative/HBV DNA positive chronic hepatitis B [abstract]. Hepatology 2000;32:459A.

11. Papatheodoridis GV, Dimou E, Laras A, Papadimitropoulos V, Hadziyannis SJ. Course of virologic breakthroughs under long term lamivudine in HbeAg negative precore mutant HBV liver disease. Hepatology 2002;36:219-26.

12. Rizzetto M. Efficacy of lamivudine in HbeAg-negative chronic hepatitis B. J Med Virol 2002;66:435-51.

13. Malaguarnera M, Restuccia S, Di Fazio I, Zoccolo AM, Trovato BA, Pistone G. Serum beta2-microglobulin in chronic hepatitis C. Dig Dis Sci 1997;42:762-6.

14. Freni MA, Ajello A, Spadaro A, et al. Class I HLA antigens hepatic display and beta2-microglobulin serum values in chronic hepatitis $\mathrm{C}$ : Effect of treatment with recombinant alpha interferon. Hepatogastroenterology 1997;44:1295-301.

15. Quiroga JA, Martin J, Pardo M, Carreno V. Serum levels of soluble immune factors and pathogenesis of chronic hepatitis $\mathrm{C}$, and their relation to therapeutic response to interferon-alpha. Dig Dis Sci 1994;39:2485-96. 
16. Kumashiro R, Ide $\mathrm{T}$, Sasaki M, et al. Interferon-gamma brings additive antiviral environment when combined with interferonalpha in patients with chronic hepatitis C. Hepatol Res 2002;22:20-6.

17. Garcia-Buey L, Lopez-Botet M, Garcia-Sanchez A, et al. Variability in the expression of a beta2-microglobulin epitope on hepatocytes in chronic type $\mathrm{C}$ hepatitis on treatment with interferon. Hepatology 1993;17:372-82.

18. Wejstal R, Norkrans G, Weiland O, et al. Lymphocyte subsets and beta2-microglobulin expression in chronic hepatitis C/non-A, non-B. Effects on interferon-alpha treatment. Clin Exp Immunol 1992;87:340-5.

19. Ishak K, Baptista A, Bianchi L, et al. Histological grading and staging of chronic hepatitis. J Hepatol 1995;22:696-9.

20. World Health Organization. Laboratory Biosafety Manual. Geneva: World Health Organization, 1993.

21. Lawless J. Statistical Model and Methods for Lifetime Data. New York: John Wiley Sons Inc, 1982.

22. Liang KY, Zeger SL. Longitudinal data analysis using generalized linear models. Biometrica 1986;73:13-22.

23. Hadziyannis SJ, Papatheodoridis GV, Dimou E, Laras A, Papioannou C. Efficacy of long term lamivudine monotherapy in patients with hepatitis B e antigen negative chronic hepatitis B. Hepatology 2000;32:847-51.

24. Buti M, Sanchez F, Cotrina M, et al. Quantitative hepatitis B virus DNA testing for the early prediction of the maintenance of response during lamivudine therapy in patients with chronic hepatitis B. J Infect Dis 2001;183:1277-80.

25. Chisari FV, Ferrari C. Hepatitis B virus immunopathogenesis. Annu Rev Immunol 1995;13:29-60.

26. Kagi D, Vignaux F, Ledermann B, et al. Fas and perforin pathways as major mechanisms of $\mathrm{T}$ cell mediated cytotoxicity. Science 1994:265:528-30

27. Guidotti LG, Ando K, Hobbs MV, et al. Cytotoxic T lymphocytes inhibit hepatitis B virus gene expression by a noncytolytic mechanism in transgenic mice. Proc Natl Acad Sci USA 1994;91:3764-8.

28. Guidotti LG, Ishikawa T, Hobbs MV, Matzke B, Schreiber R, Chisari FV. Intracellular inactivation of the hepatitis B virus by cytotoxic T lymphocytes. Immunity 1996;4:25-36.

29. Mosmann TR, Cherwinski H, Bond MW, Giedlin MA, Coffman RL. Two types of murine helper T cell clone I. Definition according to profiles of lymphokine activities and secreted proteins. J Immunol 1986;136:2348-57.

30. Bjerrum OW, Bjerrum OJ, Borregaard N. Beta 2-microglobulin in neutrophils: An intragranular protein. J Immunol 1987;138:3913-7.

31. Boni C, Penna A, Ogg GS, et al. Lamivudine treatment can overcome cytotoxic $\mathrm{T}$ cell hyporesponsiveness in chronic hepatitis B: New perspectives for immune therapy. Hepatology 2001;33:963-71.

32. Maini MK, Boni C, Lee CK, et al. The role of virus-specific CD8 $(+)$ cells in liver damage and viral control during persistent hepatitis B virus infection. J Exp Med 2000;191:1269-80.

33. Michalak TI, Hodgson PD, Churchill ND. Posttranscriptional inhibition of class I major histocompatibility complex presentation on hepatocytes and lymphoid cells in chronic woodchuck hepatitis virus infection. J Virol 2000;74:4483-94.

34. Tomita T, Yokosuka O, Tagawa M, et al. Decrease of wild type and precore mutant duck hepatitis $\mathrm{B}$ virus replication during lamivudine treatment in white Peking duck infected with the viruses. J Hepatol 2000;32:850-8.

35. Marinos G, Naoumov NV, Williams R. Impact of complete inhibition of viral replication on the cellular immune response in chronic hepatitis B virus infection. Hepatology 1996;24:991-5.

36. Suri D, Schilling R, Lopes AR, et al. Non-cytolytic inhibition of hepatitis B virus replication in human hepatocytes. J Hepatol 2001;35:790-7.

37. Santantonio T, Niro GA, Sinisi E, et al. Lamivudine/interferon combination therapy in antiHbe positive chronic hepatitis $\mathrm{B}$ patients: A controlled pilot study. J Hepatol 2002;36:799-804. 


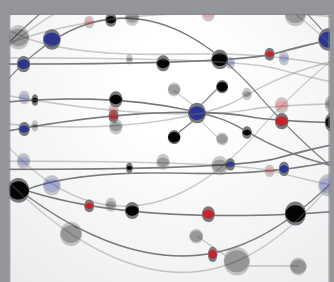

The Scientific World Journal
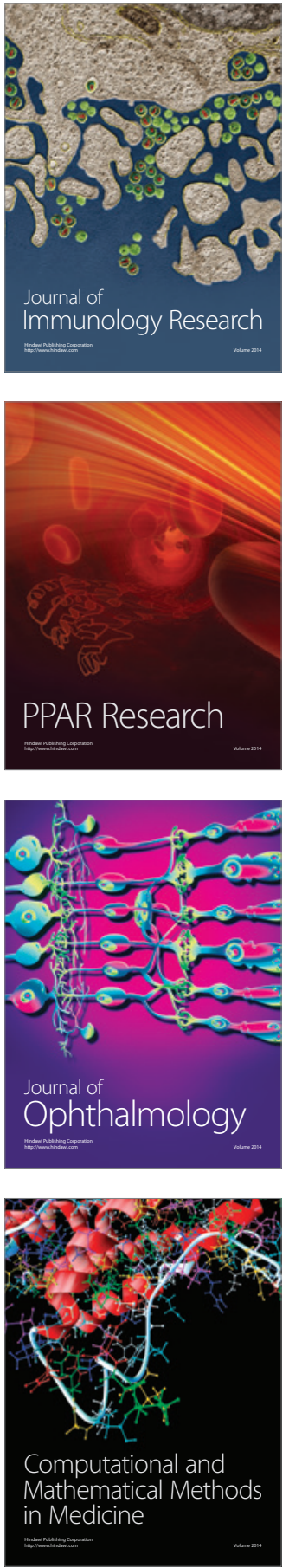

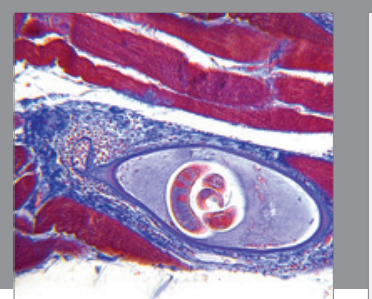

Gastroenterology Research and Practice

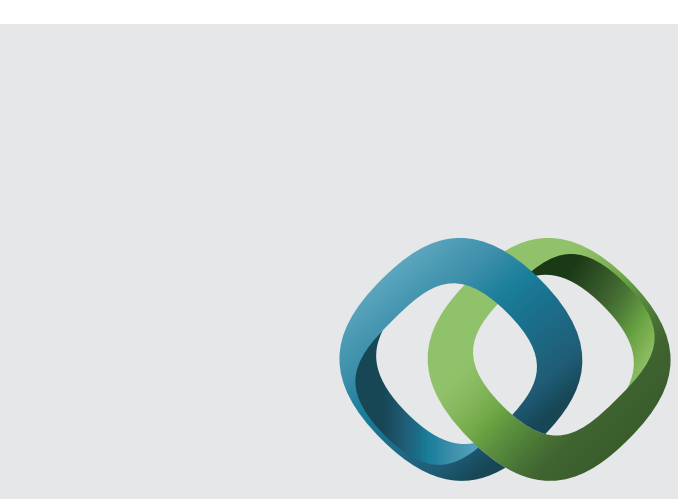

\section{Hindawi}

Submit your manuscripts at

http://www.hindawi.com
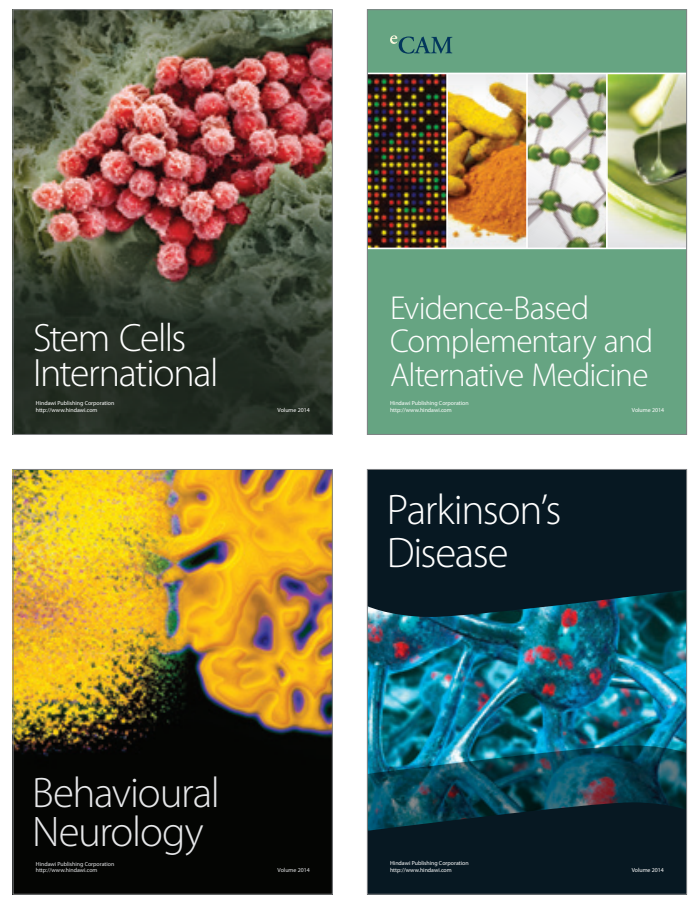
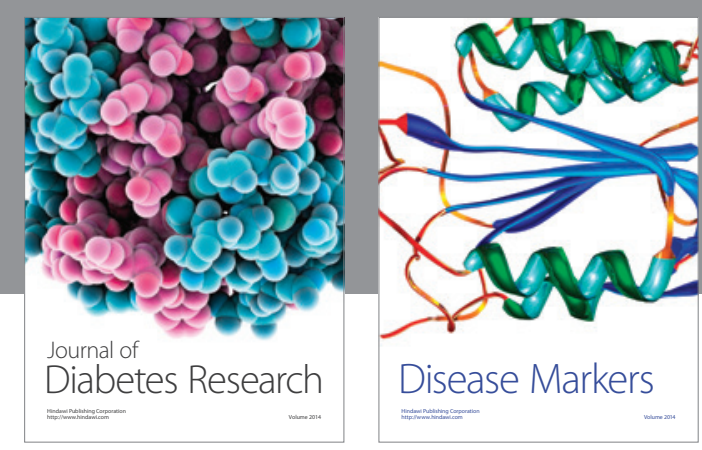

Disease Markers
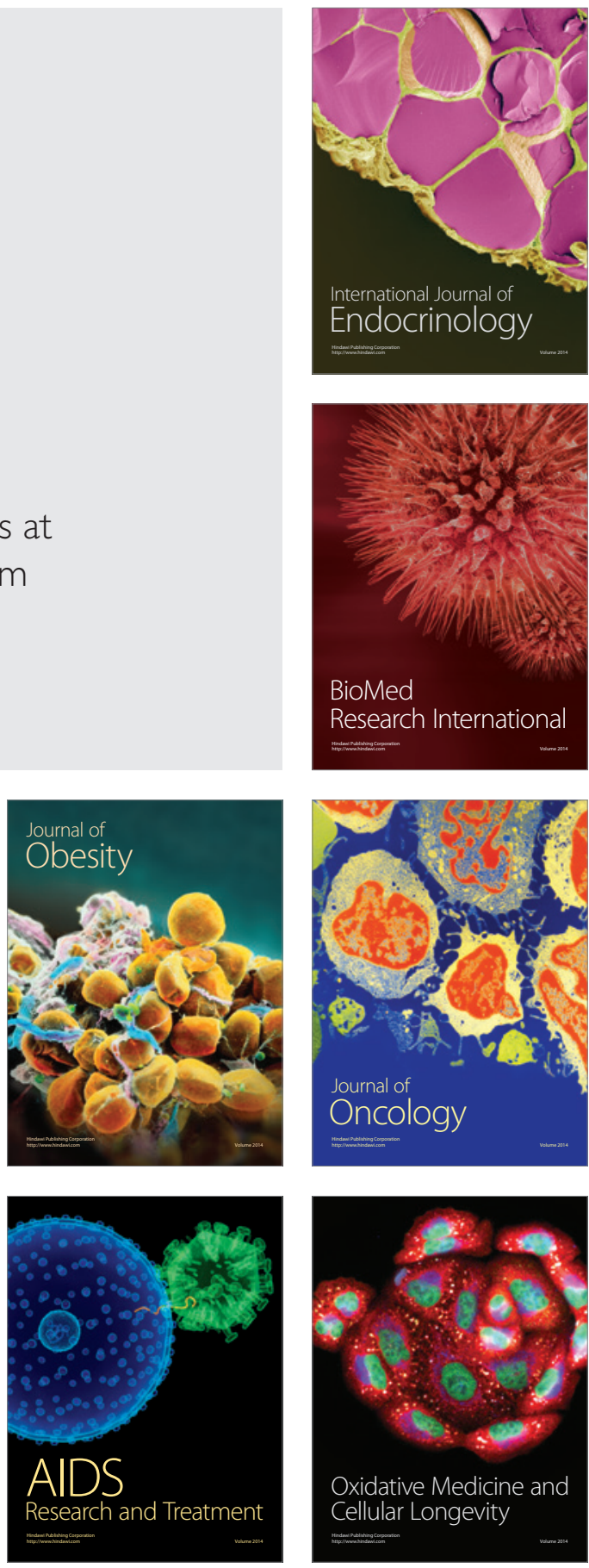